\title{
Components and Characteristics of the Professional Competency Model among Educational Administrators
}

\section{Componentes y características del modelo de competencia profesional entre administradores educativos}

\author{
Samaneh Astereki \\ Department of Educational Sciences, Khorramabad Branch, Islamic Azad University, \\ Khorramabad, Iran. \\ ORCID: https://orcid.org/0000-0002-8132-2727
}

Hossein Mehrdad

Assistant Professor, Department of Educational Sciences, Khorramabad Branch, Islamic Azad University, Khorramabad, Iran.

ORCID: https://orcid.org/0000-0001-8354-6233

\section{Moslem Ghobadiyan}

Assistant Professor, Department of Educational Sciences, Farhangiyan University Tehran, Iran.

ORCID: https://orcid.org/0000-0002-5755-0244

Received 09-08-20 Revised 10-10-20

* Correspondence

Email:sinamhr@gmail.com
Accepted 12-11-21 On line 03-04-21

\section{Citation:}

Astereki S. Mehrdad H. Ghobadiyan M. (2021)

Components and Characteristics of the Professional

Competency Model among Educational Administrators.

Propósitos y Representaciones, 9(SPE2), e1088.

http://dx.doi.org/10.20511/pyr2021.v9nSPE2.1088 


\section{Summary}

Education is the most basic institution in the development process in each country. In other words, if education is dynamic, active, and vibrant in a country, the country will naturally be a growing and developed country. Professional and effective training of professional and effective managers is one of the basic problems, whose successful and effective implementation in an organization requires a set of competencies, skills, abilities, and special characteristics. Competence is a special tool for workforce planning and management. In this regard, much attention to the competency approach stems from the capabilities of the organization. In other words, a successful and effective organization creates and maintains its competitive advantage by developing individuals' competencies. On the other hand, the competency approach is of great importance in the development of managers as they can develop and improve their performance by adopting such an approach. Accordingly, the present study aimed to investigate the components and characteristics of the professional competency model among educational administrators. The study findings revealed that the most prominent management dimension encompasses supervision and guidance, knowledge management, evaluation, decision-making, and planning. Personality dimension includes ethics, creativity and innovation, communication skills, and negotiation skills. Technological dimension consists of information literacy, application of new technologies in teaching, the use of information and communication technology, and the ability to work in a virtual environment. Educational-research dimension addresses research orientation, applied scientific research, familiarity with teaching methods and techniques, and incentives for employees to teach effectively. This descriptive-analytical study adopted a library technique.

Keywords: Professional Competence, Educational Managers, Education, Competence Model.

\section{Resumen}

La educación es la institución más básica en el proceso de desarrollo de cada país. En otras palabras, si la educación es dinámica, activa y vibrante en un país, el país naturalmente será un país desarrollado y en crecimiento. La formación profesional y efectiva de gerentes profesionales y efectivos es uno de los problemas básicos, cuya implementación exitosa y efectiva en una organización requiere de un conjunto de competencias, habilidades, habilidades y características especiales. La competencia es una herramienta especial para la planificación y gestión de la fuerza laboral. En este sentido, mucha atención al enfoque de competencias se deriva de las capacidades de la organización. En otras palabras, una organización exitosa y eficaz crea y mantiene su ventaja competitiva desarrollando las competencias de las personas. Por otro lado, el enfoque por competencias es de gran importancia en el desarrollo de los gerentes, ya que pueden desarrollar y mejorar su desempeño al adoptar dicho enfoque. En consecuencia, el presente estudio tuvo como objetivo investigar los componentes y características del modelo de competencia profesional entre los administradores educativos. Los hallazgos del estudio revelaron que la dimensión de gestión más destacada abarca la supervisión y orientación, la gestión del conocimiento, la evaluación, la toma de decisiones y la planificación. La dimensión de personalidad incluye ética, creatividad e innovación, habilidades de comunicación y habilidades de negociación. La dimensión tecnológica consiste en la alfabetización informacional, la aplicación de nuevas tecnologías en la enseñanza, el uso de tecnologías de la información y la comunicación y la capacidad de trabajar en un entorno virtual. La dimensión de investigación-educación aborda la orientación a la investigación, la investigación científica aplicada, la familiaridad con los métodos y técnicas de enseñanza y los incentivos para que los empleados enseñen de manera eficaz. Este estudio descriptivo-analítico adoptó una técnica de biblioteca.

Palabras clave: Competencia profesional, Directivos educativos, Educación, Modelo de competencia. 


\section{Introduction}

Today, all institutions face competition, and this is a challenge for managers to pay attention to activities that focus on profitability and also gain a competitive advantage for managers to understand the competitive situation in order to design a strategy that creates a competitive defensive position, inclined and motivated enough. Have.

Studies show that most of the country's organizations have not performed satisfactorily due to non-compliance with the meritocracy system and central competence in the selection and appointment of managers, disregard for the principle of productivity. In all organizations, including educational organizations, the most important and effective element to achieve organizational goals, in other words, effectiveness, is management. The failure of any organization can be attributed to a large extent to the inefficient management and leadership of that organization, which is why today they try to appoint people to positions who have the necessary ability and competencies to lead effectively.

Principals influence all aspects of schools, they run organizations whose production (product) is human, and these human beings must be built and paid enough to be easily and skillfully absorbed into the labor and life markets. Therefore, principals have the greatest impact on the goals of the school, ie students. Also, change in organizations takes place quickly, in this process, employees are expected to be more consistent than before, and managers also play an important role in playing the role model, in creating and applying values, behaviors and considerations according to By expecting employees to achieve the changes that have taken place in the organization and they have accepted this process, prepare the ground for implementing their goals and adapting themselves and their employees to these events. Accordingly, the manager must consider the public perception, the satisfaction of all. The realization of this issue is done in the shadow of managerial competencies.

\section{Statement of the problem}

In today's turbulent world, what can ensure the growing life of organizations is the existence of a powerful and efficient management system. In order to have an effective and efficient management system, powerful and competent managers must be trained (Mirsapasi, 2011). Success in playing a role and performing a heavy managerial responsibility is more than anything related to the ability and effectiveness of managers, the effectiveness of managers depends on their competence, skills, level of knowledge, insight and abilities (Khorshidi \& Ekrami, 2011). Global developments have had significant effects on the needs and functions of educational units and have changed the concept of education, its management has also changed as appropriate (Alaghband, 2012). In such circumstances, educational administrators must have more than enough knowledge, skills and attitudes to achieve the desired goals and appropriate to the current situation of schools and the environment around them. Given that individuals have a vital and decisive role in the heart of organizations, so their competencies must be strengthened, so each organization that has experienced continuous growth and sustainable success certainly possesses a team of leaders and managers. It has been worthy and efficient, and efficiency and competence will be realized only through paying attention to the promotion and improvement programs of features and competencies (Abol Alaei \& Ghaffari, 2016). Today, management and its competencies are at the top of all issues. If a manager does not have strategic thinking skills and fails to detect appropriate solutions and methods quickly, he never can lead the organization to achieve goals and use appropriate methods (Mahmoudi et al., 2016).

Managers are one of the main pillars in any organization, especially educational organizations, which play a critical role in carrying out missions and achieving the goals of the organization (Pourkarimi \& Sedaghat, 2014).

In recent years, one of the emerging issues is that its competencies and roles are a factor in helping the organization cope with the changing environment. Since the mid-1980s, the development and evaluation of managerial competencies has been the focus of organizations. The 
main reason for such attention was the belief that the development of managerial competencies brings innumerable benefits to organizations (Horton, 2013).

Education is the most basic institution in the development process of each country. In other words, if education in a country is dynamic, active and vibrant, the country will naturally be a growing and developed country. Professional and effective training of professional and effective managers is one of the basic problems that its successful and effective performance in the organization requires a set of competencies, skills, abilities and special characteristics. Competence is a special tool for workforce planning and management. In this regard, much attention to the competencies approach stems from the capabilities of the organization. In other words, a successful and effective organization creates and maintains its competitive advantage by developing the competencies of individuals. On the other hand, the competencies approach is highly important for the development of managers because through this they can develop and improve their performance (Horton, 2013).

In all organizations, including educational organizations, the most remarkable and effective element to achieve organizational goals, in other words, effectiveness, is management. In education-oriented organizations such as education, management has a much more important and fundamental role and position. In such an environment, there is a need for managers who can make the right decisions, provide creative solutions to problems and be accountable for their work. In addition, the comprehensive expansion of educational organizations requires the need for capable and skilled managers in applying knowledge. And the specialized experience has doubled. Accordingly, the duties and functions of educational managers in the form of their skills and competencies is one of the main issues that have long been considered by managers and management science specialists. In educational organizations in terms of type of activity, methods of implementation and its complex goals of management and educational leadership have a special place. Studies show that most organizations in our country have not performed satisfactorily due to non-compliance with the meritocracy system and central competence in the selection and appointment of managers and disregard for the principle of productivity (Taslimi et al., 2013).

Many experts believe that school principals play a pivotal role in effectiveness and that the performance of educational administrators and leaders contributes significantly to students' academic success (Supovitz et al., 2019). In addition to the significance of school management, the secondary education course is of particular importance for two reasons, one is that the majority of graduates of this course enter the labor market directly and will probably not have another opportunity for formal education. Second, those admitted to the entrance exam, universities and institutions of higher education are second-year graduates, so the quantity and quality of education will have a direct impact on the outcome of this course. Since the competencies and abilities of principals affect the academic success of students, the output of high school graduates will overshadow the needs of the labor market and higher education (Noorbakhsh Dehkordi, 2004).

The importance and sensitivity of the behavior of educational administrators is such that sometimes it is impossible to compensate for their negative effects, so it is necessary for school administrators to have the necessary ability and competence in this field. Alaghband believes that educational managers, in addition to knowledge and information in the field of education and psychology and mastery of practical methods and skills, should have sufficient educational background to be able to the main mission and problems of their work. To understand correctly, in addition to being prone in terms of personality and adhering to moral principles and standards in order to be able to prevent deviations and deviations in the educational environment and to be an example and head of students by their behavior and actions (Alaghband, 2012).

\section{Definition of concepts}

Today, competence has become a multi-purpose term that is used with different meanings in various scientific fields (Mojab et al., 2018). Competence is like an umbrella that encompasses anything that directly or indirectly affects job performance. In other words, it shows the image of a grown man who is fully prepared to do a job in any way. In this regard, competency has a kind of 
systemic attitude towards employees that includes all those attributes, characteristics, attitudes related to effectiveness in performing tasks and responsibilities, thus competencies can be considered as behavioral dimensions that affect performance. Jobs have an impact.

Competencies show individuals how to do their job or how to react in certain situations. Given that human beings have a vital and decisive role in the heart of organizations, so their competencies should be strengthened. Accordingly, each organization that has experienced continuous growth and sustainable success, certainly has a team of competent and efficient managers and leaders, and efficiency and competency will be achieved only through attention to programs to improve and improve the characteristics and competencies (Abol Alaei \& Ghaffari, 2016).

Competencies are defined as a set of related knowledge, characteristics, attitudes and skills that have a great impact on individuals' jobs, are correlated with individuals' performance at work, can be evaluated using acceptable standards, and can be improved via education and development (Sanchez, 2010). (Mirsapasi, 2011) considers competency to include characteristics and behaviors that lead to the effectiveness of the individual in the work environment and includes elements of knowledge, skills, attitudes, insights and personal and behavioral characteristics that are related to organizational goals. Goals play a key role. (Beltyukova et al., 2015) defines professional competence as the ability to achieve success based on skills, knowledge and experience when performing tasks and solving problems in professional activities. In other words, competency means a combination of abilities or capabilities of the individual, including, motivation, traits, selfimage, social role or body of work-related knowledge. (Tomastika et al., 2015) states that managerial competencies include abilities and skills that contribute to the excellent performance of managers in critical situations. (Armstrong, 2013) considers competency as a set of skills, personality traits, interests and experiences and job-related competencies that enable the holder to perform at an above-average level of responsibility; competency provides a model. Which indicates a superior person or performance in the assigned job (Taslimi et al., 2013).

According to (Alaghband, 2012), competence is a combination of motivations and characteristics, self-image, attitudes or values, content knowledge or behavioral, cognitive skills. Any individual trait that can be reliably measured or ordered and can be shown to differentiate between individuals. (Abdollahi, 2015) consider competency as a group of related knowledge, skills and attitudes that affect a large part of a person's job and are correlated with job performance.

According to the International Society of Performance, a set of knowledge, skills, and attitudes that enable employees to perform job-related or job-related activities to the expected and effective standards is called competency. According to the abovementioned definitions, most of the definitions of competence refer to knowledge, ability, skills, personal characteristics, behaviors and competencies that are related to organizational goals and play a key role in achieving goals.

In general, managers' competence refers to a set of knowledge, skills, behaviors and attitudes that a person needs to act in a wide range of managerial and organizational jobs (Pillay, 2008). In a way that leads to their effectiveness in the work environment and ultimately the effectiveness of the organization. The Institute of Project Management (2004) outlines the competency dimensions as follows: Abilities: The quality of the ability to do something, the skills and the natural number acquired Attitudes: Relatively stable feelings, beliefs, and behavioral tendencies and orientations toward specific individuals, specific groups, issues, and specific goals (Najafi et al., 2018).

Behavior: The way in which a person acts in a particular situation or directs an encounter in that situation.

Knowledge: A set of conceptual, factual, and systematic information that can be used directly in the performance of tasks. 
Personality: A unique, relatively stable organization of a set of characteristics, tendencies, and traits that describe a person and determine his or her interaction with the environment.

Skills: Mastery, ease, skill and dexterity gained through internship and experience.

Providing a competency model for educational administrators can be an acceptable way in selecting and appointing competent principals to take steps towards sustainable development with the selection and presence of competent principals in schools.

\section{Materials and Methods}

This research is field type in terms of environment and is cross-sectional in terms of time and also according to the purpose and nature, it is descriptive and correlational that the combined or mixed (qualitative-quantitative) research method has been used. The present study is an applied goal that is done with an approach mixed with exploratory design. In the qualitative approach, purposive sampling method is used and in the quantitative approach, the descriptive survey method is used.

\section{Results}

Components and characteristics of the proposed model of professional competencies of managers a Managerial dimension.

The components of this dimension are as follows:

1. Supervision and guidance: The component of supervision and guidance, which means work and effort based on professional cooperation and joint efforts and includes a set of activities designed to improve the teaching and learning process.

2. Knowledge management: The second component in the management dimension is the knowledge management component, which refers to a set of processes that control the creation, dissemination and application of knowledge in an organization, which includes explicit knowledge and enabling the environment for development, cultivation, Apply and share the technical knowledge of employees.

3. Evaluation: The third component in the management dimension is evaluation. This component refers to the process of detecting, observing, measuring and improving human performance in organizations. Evaluation means systematically measuring the performance of employees and determining their competencies, abilities and shortcomings in relation to a particular job.

4. Decision making: Decision making is another component of the management dimension. This means that the decision is to choose one of the various ways. Deciding how to act or move in a certain direction is carefully and consciously selected from different ways and methods to achieve a desired goal.

5. Planning: The planning component, which means a process with specific and interconnected steps to produce a coherent output in the form of a coordinated system of decisions, in relation to the activities necessary to achieve the desired goal.

\section{Personality dimension}

The components of this dimension are as follows:

1. Ethics: The component of professional ethics is one of the components of the personality dimension of the proposed model. This component refers to a set of ethical actions and reactions adopted by organizations and professional associations to provide the most desirable social relationships possible for its members in the performance of professional duties, in other words, professional ethics It is used in the initial conceptualization to mean work ethic and job ethics. 
2. Creativity and Innovation: The Creativity and Innovation component refers to combining ideas and opinions in a unique way by creating a connection between them and taking creative ideas and turning them into new products, services and methods of operation. 3. Communication skills: The communication skill component, which refers to the concept of transferring information, emotions from one person to another or other individuals, is one of the important processes that play a key role in the success of managers and their effectiveness.

4. Negotiation Skills: The negotiation skills component means a conversational process with body language, and the art of negotiation is based on the principle that the parties try to create a common ground between their desired outcome and the outcome of the other party.

\section{Technological dimension the components of this dimension are as follows}

1. Information literacy: The component of information literacy, which is one of the prominent features of an information society that allows a person to easily access information to meet their information needs, use and examine them and It has been described and described as the basis for individuals to achieve their personal, social, professional and educational goals.

2. Application of new technologies in teaching: The component of application of new technologies in teaching, which as one of the essential factors and facilitator of the educational system in this course according to the special characteristics of students in this course can pave the way for better development and application This is the case in other academic levels as well.

3. Use of information and communication technology: The skill component of using information and communication technology means using technology as an educational innovation to enrich the learning environment, active student involvement, facilitating metacognitive approaches, interactive and participatory learning and resource enrichment Learning helps. Technology is considered to be the systematic application of all sources of organized knowledge such as literature, science, and art.

4. Ability to work in the virtual environment: The ability to work in the virtual environment that refers to the skill in using information in the virtual environment to obtain the best educational information of the day and establish the best communication to exchange information through cyberspace and optimal use of virtual facilities.

\section{Discussion}

Educational-research dimension, the components of this dimension are as follows: 1. Researchoriented: Research-oriented component, which means the application of research findings in decisions and planning by managers and planners of the educational system and is a turning point and existential philosophy of developing and strengthening research activities. 2. Conducting applied scientific research: Conducting applied scientific research refers to having a strategic plan in the field of research in education and culture, creating a system of scientific and research information, development, and scientific research training, and creating a positive attitude. To apply scientific findings in education and establish an information system, educational research and communication among university researchers, education and professional development, and teacher training in the field of courses and research methods leads to the development of research management. 3. Familiarity with teaching methods and techniques: The familiarity with teaching methods and techniques refers to the knowledge or science of education that is in the field of curriculum content and scientific information and practical skills that lead to effective learning.

4. Encourage staff to teach effectively: The component of encouraging staff to teach effectively, which means examining the effectiveness of educational activities, which includes teaching skills, motivation, personality, classroom behavior, and the teacher's scientific ability.

Competence seems to be like an umbrella encompassing anything that directly or indirectly affects job performance. Competency has a kind of systemic attitude towards employees 
that includes all those attributes, characteristics, attitudes related to effectiveness in performing tasks and responsibilities, thus competencies can be considered as behavioral dimensions that affect performance. Jobs have an impact. Accordingly, each organization that has experienced continuous growth and sustainable success, certainly has a team of competent and efficient managers and leaders.

\section{Conclusion}

Based on the information obtained from the fit of the research model, it can be concluded that the four dimensions of the professional competency model have a favorable fit among educational administrators. Accordingly, providing a model of competencies of educational administrators can be an acceptable way to select and appoint competent administrators to take steps towards sustainable development with the selection and presence of competent administrators in schools. Accordingly, professional competencies are fully accepted as a necessity in today's organizations, and organizations provide a set of solutions for all management processes and professional competencies in various areas of management, personality, technology, and education and research.

\section{References}

Abdollahi, M. (2015). Designing a Competency-Based Education and Improvement Model for Educational Managers of Organizations (Industry-Idro Education Managers), PhD Thesis in Educational Management, Faculty of Management, Islamic Azad University. Science and Research Branch, 8(1), 54-60.

Abol Alaei B. \& Ghaffari A. (2016), Competency model of managers of Iran. Industrial Development and Renovation Organization, 18(1), 147-168.

Alaghband A. (2012). Educational management in the collection of articles on the nature and scope of educational sciences. Samat Publications, 15(2), 155-180.

Armstrong, M. (2013). A Handbook of Human Resource Management Practice 10th Edihon. Philadelphia: Kogan Page, 11(6), 114-130.

Beltyukova, N., Grishaeva, A., \& Karataeva, N. (2015). Foreign-Language Project - based Method as Means of Forming Professional Competence in Bachelors of Management Procedia. Social and Behavioral Sciences, 20(1), 398-402.

Horton, R. (2013). Motivation Reconsidered: The Concept of Competenc. Psychological Review, 6(6), 279-333.

Khorshidi A. \& Ekrami M. (2011). Identifying the Constituent Factors of Managers' Competence. Scientific Research Quarterly, 6(4), 14-29.

Mahmoudi, I., \& Abedi, A., \& Heidari, Y. (2016). Assessing the professional competence of department heads. Management and Development Process, 15(5), 93-96

Mirsapasi N. (2011). Strategic Management of Human Resources and Labor Relations. Tehran: Mir Publications, 12(4), 23-38.

Mojab, F., Zaefarian, R., \& Dazian Azizi, A. (2018). Applying Competency based Approach for Entrepreneurshipe Education. Procedia Social and Behavioral Sciences, 8(12), 436-447.

Najafi, M., Qahramani, M., Abul Ghasemi, M., \& Arefi, M. (2018). Designing and explaining the model of professional competencies of preschool center managers. Scientific Research Quarterly, 9(2), 88-95.

Noorbakhsh Dehkordi K. (2004), A study of the skills of principals of girls' high schools in Isfahan and its comparison with the skills required by educational administrators. Quarterly Journal of Management in Education, 10(8), 25-37.

Pillay, R. (2008). Defining Competencies for Hospital Management a Comparative Analysis of the Public and Private Sector. Leadership in Healt Services, 21(2), 99-110.

Pourkarimi, J., \& Sedaghat, M. (2014). Explaining the relationship between competence, transformational leadership style of managers of research organizations. Human resource management research, 19(1), 201-222.

Sanchez, J. (2010). Univercity Training for Entrepreneurial Competencies it is Impact on Intention of Creation. Springer science Business Media, 12(3), 159-170. 
Supovitz, J., Sirinides, P., \& May, H. (2019). How Principals and Peers Influence Teaching and Learning Educational. Administration Quarterly, 20(5), 46-59.

Taslimi, M., \& Rai, R., \& Farzin, V., \& Asadaleh. B. (2013). Designing and explaining the competency model of national project managers with a focus on risk. Government management, 18(1), 115-139.

Tomastika, M., Stroh Mandlb, J., \& Cechc, D. (2015). Managerial Competency of Crisis Managers. Procedia-Social and Behavioral Sciences, 17(4), 180-197. 